\title{
Contributory pension scheme and employee work attitude in the Nigerian Federal Civil Service
}

\section{Chiemeka Onyema}

Imo State University. Owerri. Nigeria. Email: emekaonyema4@gmail.com.

\begin{abstract}
This study investigated the effects of Contributory Pension Scheme on employee work attitude in the Nigerian Federal civil service. The study which is anchored on expectancy theory adopted a cross-sectional survey design. A sample of 1007 federal civil servants selected using total population sampling technique constituted the study participants. A structured questionnaire with a reliability co-efficient estimate of 0.742 was used to generate the quantitative data. The Statistical Package for Social Sciences (SPSS) aided the presentation and analysis of data relating to the objectives of study using frequency distribution table and, the test of research hypothesis with chi-square statistic. The study's findings suggest that contributory pension scheme has had positive effects on employee work attitude in the Nigerian Federal civil service in Imo State. The study found a statistically significant relationship between the new contributory pension scheme and improved employee work attitude in the Nigerian federal civil service in Imo State. Based on the findings, the study recommended that government should strengthen the administration of the contributory pension scheme to further improve the work attitude of Nigerian civil servants and to enhance their efficiency.
\end{abstract}

Keywords: Civil service; Contributory pension scheme; Employee work attitude; Pension; Pension administration.

Resumo. Regime de pensão contributiva e atitude laboral do trabalhador na Função Pública Federal da Nigéria. Este estudo investigou os efeitos do regime de pensão contributiva na atitude de trabalho dos funcionários no serviço público federal nigeriano. 0 estudo, ancorado na teoria da expectativa, adotou um desenho de pesquisa transversal. Uma amostra de 1.007 servidores públicos federais selecionados pela técnica de amostragem da população total constituíram os participantes do estudo. Um questionário estruturado com estimativa de coeficiente de confiabilidade de 0,742 foi utilizado para gerar os dados quantitativos. O SPSS auxiliou na apresentação e análise dos dados relativos aos objetivos do estudo por meio de tabela de distribuição de frequência e, no teste de hipótese de pesquisa com a estatística qui-quadrado. Os resultados sugerem que o regime de pensão contributiva teve efeitos positivos sobre a atitude de trabalho dos funcionários no serviço público federal nigeriano no
Received

May 08, 2021

Accept

July 26, 2021

Available online July 31, 2021

Released

August 31, 2021

Open Access

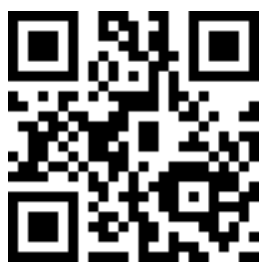

ORCID

(1) 0000-0002-4147-8751 Chiemeka Onyema

ISSN 2359-1412/RBGAS-2021-0044/2021/8/19/22/957

Rev. Bras. Gest. Amb. Sustent.

http://revista.ecogestaobrasil.net 
Estado de Imo. 0 estudo encontrou uma relação estatisticamente significativa entre o novo regime de pensão contributiva e a melhoria da atitude de trabalho dos funcionários no serviço público federal nigeriano no Estado de Imo. Com base nas conclusões, o estudo recomendou que o governo deve fortalecer a administração do regime de pensões contributivas para melhorar ainda mais a atitude de trabalho dos funcionários públicos nigerianos e aumentar sua eficiência.

Palavras-chave: Função pública; Regime de pensão contributiva; Atitude de trabalho do empregado; Pensão; Administração de pensões.

\section{Introduction}

The civil service was originated as an efficient way of organizing large number of people towards achieving specific public objectives. The term 'civil service' is most often used to classify the body of employees who work in government Ministries, Departments and Agencies (MDAs), or to refer to the MDAs in which public employees work. The civil service has over the years evolved as the central institution through which government implements its policies and programs designed to meet political aims and provide social services. In reference to the State, the civil service provides the semblance of government. Ultimately, the effectiveness and efficiency of government as a public administration agency of the state is largely determined by the efficiency of the civil service (Kwaghaga, 2010).

The rapid social changes occurring in Nigeria in recent times have heightened the demands and expectations of Nigerians for better governance through effective service delivery, transparency, accountability, and adherence to the rule of law. Nigerians expect the civil service as the primary machinery of public administration to not only implement government policies on a day-to-day basis, but also to play significant roles in formulating and implementing development strategies and programs that will stimulate accelerated positive social and economic development. The desired socio-economic development is naturally expected to include reduced unemployment, increased social products and a more equitable redistribution of income. So far, these desires remain unfulfilled evinced by the high rate of poverty, inadequate physical infrastructure, high level of bureaucratic corruption and unemployment (Lawal e Oluwatoyin, 2011).

The performance of the Nigerian civil service in recent times has been a major source of worry to Nigerians due to its negative impact on national development. Some Nigerians, for example, Obasanjo (2004), see the civil service as an institution that has contributed greatly to the underdevelopment of the nation. Obasanjo blames the civil service for the dislocation and distortion of the national development plans, projects and programs, demonstrated by the uncompleted or abandoned strategic projects, criminal waste of resources, and dilapidated public facilities. The quality of personnel in the civil service is said to have deteriorated, manifesting in low technical know-how, low productivity, and high level of corruption (Adegoroye, 2006). Okonjo-Iweala and OsafoKwaako (2007:14) observed "a weak work ethic and poor service delivery by many government ministries, often characterized by hidden or outright corrupt behaviour on the part of many civil servants". According to Iheriohanma (2006) employee performance in the Nigerian public service has continued to dwindle and low productivity is been recorded in all public sector organizations. 
The reforms implemented by past Nigerian governments, for example, the ones undertaken through the Adebo Commission of 1970, Udoji Commission of 1974, and the Ayida Panel of 1995, accentuate the efforts made to improve the work attitude and performance of Nigerian civil servants. A more recent reform is the Public Service Renewal Programme initiated by the Obasanjo-Led Administration in the Fourth Republic. The key ideology behind the Obasanjo Administration's Public Service Renewal Programme (PSRP) is to fashion a civil service that is service-result and -technology oriented, thereby instituting a New Public Management paradigm (Adegoroye, 2006). The PSRP introduced policies such as Monetization of Fringe Benefits, Service Compact (SERVICOM), and the Contributory Pension Scheme, which is the focus of this study.

The Contributory Pension Scheme became operational with the enactment of the Pension Reform Act 2004, and the setting up of the National Pension Commission (National Pension Commission, 2014). The rationale for the Contributory Pension Scheme (CPS) include: unsustainable pension liabilities, weak and inefficient administration of pension schemes in both private and public sectors, and the existence of diversified arrangement which were largely unregulated in the private sector (Ahmad, 2020). In other words, the contributory pension scheme was introduced basically to arrest the arbitrary increase in the cost of paying retirement benefits and to remedy the inefficiencies in the Pension Administration System. The 2004 Pension Reform Act was later amended and repealed by the Pension Reform Act 2014, to continue to govern and regulate the administration of the uniform contributory pension scheme for both the public and private sectors in Nigeria (National Pension Commission, 2018).

Despite these efforts, there are still cases of embezzlement of pension funds, late and non-payment of pensions. The alleged case of the embezzlement of Police Pension Funds by the Chairman of the Task Team on Pension Reform, in connivance with some other civil servants serving at the Police Pension Office, is sufficient proof of the loopholes in the management of workers' pension (Vanguard, 2013). There are many cases of retirees who do not receive pension after many years of retirement. These could be demoralizing for public servants as they are likely to worry about their welfare after retirement. The resultant effect could be the high rate of public corruption as public servants aim to amass wealth for life in retirement. This makes it imperative to investigate the effect of the new contributory pension scheme on employee work attitude in the Nigerian civil service. The study tests the assumption that there is a significant relationship between the new contributory pension scheme and improved employee work attitude in the Federal Civil Service, Imo State.

\section{Contributory Pension Scheme}

Employee retirement scheme has been a major concern for public organizations in Nigeria due to the cost of catering for retirees' benefits, particularly the payment of their monthly pension for as long as they live. The burden of payment of pension benefits to retired public servants in Nigeria was borne entirely by the federal, state and local governments prior to the introduction of the contributory pension scheme. Then, pension benefits were paid only through budgetary allocations.

The evolution of a pension scheme in Nigeria is usually traced to 1951 when the British Colonial Administration enacted the Pension Ordinance (Barrow, 2008). Ever since, several pension enabling Acts have been provided. Some of the enabling Acts are the Pension (Special Pensions) Act of 1961, Pension (Statutory Corporation Service) Act of 1961, and Pensions Act of 1979 (Decree No. 102/1979). The central feature of the pension schemes established by the above-mentioned Acts is the non-participation of public servants in the provision of pensions. The Acts provided that public organizations should operate a Definite Benefit (Pay-As-You-Go) Pension Scheme. Therefore, final entitlements are based on length of service and terminal emoluments. Such arrangement was fraught 
with many challenges and had a lot of pitfalls such as huge pension cost, inadequate pension funds, poor record keeping, uncoordinated administration, late payment of pensions, embezzlement of pension funds, and payment of pensions to ineligible persons (Ayegba et al., 2013; Edogbanya, 2013).

The shortcomings of the earlier pension schemes in Nigeria necessitated the enactment of the 2004 Pension Reform Act (PRA) by the Obasanjo-led Administration. Contrary to previous schemes, the 2004 Pension Reform Act stipulates a Contributory Pension Scheme. The Contributory Pension Scheme requires the employee and his/her employers to contribute cumulatively a minimum of $15 \%$ (7.5\%, respectively) of the monthly emoluments (consisting of basic salary, housing and transport allowances) of the employee covered by the scheme. The contributed pension funds are to be deposited in the employee's Retirement Savings Account (RSA) which would be held by the Pension Fund Custodian (PFC). An employee's pension fund is to be managed by the Pension Fund Administrator (PFA) under the supervision of the National Pension Commission, the statutory body charged with responsibility of regulating the administration of the contributory pension scheme in Nigeria (National Pension Commission, 2014).

The objectives of the contributory pension scheme as stipulated by the 2004 Pension Reform Act include: to ensure that every person who has worked in the public (or private) sector of the federation receives his or her pension as and when due; to establish uniform rules, regulations and standards for administration of pension matters; and, to establish strong regulatory and supervisory framework (Ahmad, 2020). The broad intention is that the contributory pension scheme would help to motivate active public servant towards enhanced performance. As Sule and Ezugwu (2009) posit, good pension scheme guarantees employee's comfort and commitment to the organization. Conversely, a poor pension scheme results in low morale, weak commitment to work, fear of retirement, falsification of age, bureaucratic crime, and high labour turnover (Agba et al., 2008).

Contributory Pension Scheme and Employees Work Attitude and Behaviour Allen and Clark (1987) examined how pension plans affect employee behaviour and firm performance. Their findings suggest that firms with pensions should have lower turnover rates, and their employees will be less likely to shirk. Allen and Clark (1987) claim that pension coverage is associated with higher productivity. According to Dorsey et al. (1998:11), pensions establish incentives that promote productivity. They claim that pension-covered workers experience lower quit and layoff rates and are more likely to receive training (Dorsey et al., 1998:77). In their view, defined-contribution coverage is associated with favourable labour market outcomes because it attracts workers who are inherently more forward looking and presumably better employees (Dorsey et al., 1998, p. 77).

Sule and Ezugwu (2009) evaluated whether the application of the contributory pension scheme has an impact on employee retirement benefits of quoted firms in Nigeria. The findings revealed that the application of the contributory pension scheme has positive impact on employee retirement benefits of quoted firms in Nigeria. Chizueze et al. (2011) investigated the impact of contributory pension scheme on workers commitment, retention, and attitude towards retirement. Their findings revealed that contributory pension scheme significantly affects workers' commitment to work, retention, and attitude towards retirement.

Kotun et al. (2016) investigated the effects of contributory pension scheme on employees' productivity in Lagos State, Nigeria and found that there is significant relationship between adequate retirement package and employees' productivity. Their findings suggest that contributory pension scheme (CPS) has a positive impact on the organization efficiency and that CPS has positive potentials over the defined benefits pension scheme (DBPS). Eze and Anikeze (2018) investigated the effect of Contributory 
Pension Scheme (CPS) on workers' performance in Federal Universities in South East Nigeria and found that the scheme has enhanced workers attitude to work. The study also established that Contributory Pension Scheme has had positive effect on workers' morale and job satisfaction.

Few scholars are not totally convinced about the efficacy of the contributory pension scheme in solving the problems of retirees and of productivity in Nigeria. For instance, the findings of the study by Dagauda and Adeyinka (2013) indicated that though the implementation of the contributory pension scheme significantly improved the welfare of civil servants, it did not address the problem of corruption and inadequate budgetary allocation and therefore not effective in overcoming the problems of retirees in Nigeria. Egye and Uthman (2018) examined the justification of the reform of the pension industry in Nigeria and its impact on productivity in Federal Polytechnic, Nasarawa. They found that the 2004 pension reform has not influenced productivity and that the reform is bedeviled by so many challenges. The mixed results from the reviewed empirical studies, justify the present study on the effect of contributory pension scheme on employees' work attitude in the Nigerian civil service.

\section{Theoretical framework}

\section{Expectancy theory}

This work is anchored on the expectancy theory of motivation proposed by Victor Vroom in 1964. Expectancy theory assumes that behaviour results from conscious choices among alternatives whose purpose is to maximize pleasure and to minimize pain. Put differently, the theory states that individuals will be motivated to engage in certain behaviours if they think that those behaviours will lead to desirable outcomes. The focus of Vroom's expectancy theory was "on factors involved in stimulating an individual to put effort into something, since this is the basis of motivation" (Cole, 1996, p. 40).

The core of the expectancy theory relates to how an individual perceives the relationship between effort, performance and rewards. The perception of the relationship between effort and performance is referred to by Vroom as expectancy. The link between performance and a specific outcome is known as instrumentality; while the perception of the desirability of a reward (outcome) is tagged valence (Vroom, 1964). "According to Vroom, the three factors, expectancy, instrumentality and valence, combine together to create a driving force (Force), which motivates an individual to put in effort, achieve a level of performance, and obtain rewards at the end" (Cole, 1996, p. 41).

An application of the expectancy theory to a workplace setting such as the Nigerian Federal civil service, implies that employees will only be motivated to exert a high level of effort when they believe that: effort will lead to a good performance appraisal; a good appraisal will lead to organizational rewards such as a promotion and a salary increase; and that, the rewards will satisfy their personal goals. In other words, if employees perceive the relationship between performance and reward as weak, they will not bother to put in sufficient effort. In relation to pension, employees are likely to put in sufficient effort when they see or believe that their efforts will be rewarded even in retirement. On the other hand, employees are likely not to bother about the work effort if they believe that their retirement benefits will not be sufficient or paid on time. Employees usually form such opinions based on the treatment meted out to their colleagues who are retired.

Therefore, no matter of how well thought out reform policies are, especially pension reforms, they would likely not achieve their desired purpose until the relationship between effort and performance, as well as performance and outcome, is strengthened. It is then pertinent, that the management of organizations such as the Nigerian Federal Civil Service establish clear linkages, as failure to do so may impact employees work attitude 
and performance on the job, as employees are led to believe that their increased effort will provide little or no benefit.

The major criticism of Vroom's expectancy theory stems from its lack of explicitness in defining and distinguishing between actions and outcomes and between the different types of expectancies associated with each (Campbell et al., 1970). Some other critics such as Graen (1969) and Lawler (1971) suggest that the theory has only limited use. They argue that it tends to be more valid for predicting in situations in which effortperformance and performance-reward linkages are clearly perceived by the individual (Robbins e Judge, 2008). The critics also claim that the theory is idealistic because a few individuals perceive a high correlation between performance and rewards in their job. Ironically, this criticism can be used in support of Vroom's expectancy theory because it explains why a significant segment of the workforce exerts low levels of effort and enthusiasm in carrying out their job responsibilities.

\section{Materials and methods}

This work was designed as a cross-sectional descriptive survey. This method is justified by the assumption that there are very many similar elements in any population. Therefore, what one finds out for one element could stand for the rest of the elements which are similar to it (Unanka, 2000). A total survey of the entire study population of 1086 federal civil servants in 32 Federal establishments was attempted. However, only 1007 federal civil servants responded adequately to the research questionnaire. Therefore, a sample of 1007 , representing $92.7 \%$ of the study population, supplied data for the study.

The research questionnaire which was designed to elicit data on the effects of contributory pension scheme on employee work attitude in the Nigerian Federal Civil Service was subjected to a reliability test using Cronbach's alpha. The reliability test revealed a coefficient estimate of 0.742 , which indicated a high level of internal consistency of the questionnaire, and therefore justified its reliability as a research instrument. The questionnaire data were analysed with descriptive and inferential statistics using the Statistical Package for Social Sciences (SPSS). The SPSS aided the presentation and analysis of data relating to the objectives of study using frequency distribution table, and the test of research hypothesis with chi-square statistic.

\section{Results and discussion}

The survey data were analysed to answer the research objectives and to test the research hypothesis. To achieve the study objective, which was to investigate the effect of contributory pension scheme (CPS) on employee work attitude in the Nigeria Federal civil service, respondents were asked some questions. When respondents were asked whether the introduction of CPS has improved their job satisfaction, the majority, $67.1 \%$, of the 1007 respondents said 'yes', 23.3\% said 'they were not sure', and 9.6\% said 'no'. When respondents were asked whether the introduction of CPS helped to reduce their retirement-related-work-stress, 59.9\% (603) said 'yes', 27\% (272) said 'they were not sure', while $13.1 \%$ (132) said 'no'. In terms of whether the introduction of CPS has enhanced their job commitment, the majority (54.4\%) of the respondents answered 'yes', $32.5 \%$ said 'they were not sure', and $13.1 \%$ said 'no' (Table 1 ). The data analysis reveals that the majority of respondents confirmed that the introduction of Contributory Pension Scheme has helped to improve their job satisfaction, reduce their retirement related work stress, and to enhance their job commitment. 
Table 1. Respondents' views on the effect of Contributory Pension Scheme (CPS) on employee work attitude.

\begin{tabular}{|c|c|c|}
\hline Questionnaire items and response categories & Frequency & Percentage (\%) \\
\hline \multicolumn{3}{|c|}{ Has the introduction of CPS improved your job satisfaction } \\
\hline Yes & 676 & 67.1 \\
\hline Not sure & 234 & 23.3 \\
\hline No & 97 & 9.6 \\
\hline Total & 1.007 & 100.0 \\
\hline \multicolumn{3}{|c|}{ Has the introduction of CPS helped to reduce your retirement related work stress } \\
\hline Yes & 603 & 59.9 \\
\hline Not sure & 272 & 27.0 \\
\hline No & 132 & 13.1 \\
\hline Total & 1.007 & 100.0 \\
\hline \multicolumn{3}{|c|}{ Has the introduction of CPS enhanced your job commitment } \\
\hline Yes & 548 & 54.4 \\
\hline Not sure & 327 & 32.5 \\
\hline No & 132 & 13.1 \\
\hline Total & 1.007 & 100.0 \\
\hline
\end{tabular}

\section{Test of research hypothesis}

Table 2 shows the chi-square test of research hypothesis, which states that there is a significant relationship between the new contributory pension scheme and improved employee work attitude in the Federal civil service in Imo State. The chi-square test shows that the $p$-value $=0.000$, for $\mathrm{X}^{2}=70.191$, with $\mathrm{df}=8$, is less than 0.05 . Since $p$-value $<0.05$, hence the research hypothesis is accepted.

Table 2. Chi-square test of research hypothesis.

\begin{tabular}{|l|c|c|c|}
\hline Variable & Value & Df & Asymp. Sig. (2-sided) \\
\hline Pearson Chi-Square & $70.191^{\mathrm{a}}$ & 8 & 0.000 \\
\hline
\end{tabular}

Df, degrees of freedom; Asymp.Sig., asymptotic significance; Dependent variable = improved employee work attitude; Significant at level of 0.05 .

This study investigated the effect of Contributory Pension Scheme (CPS) on employee work attitude in the Nigerian Federal Civil Service, Imo State. The findings suggest that the introduction of Contributory Pension Scheme (CPS) has helped to improve employee job satisfaction and employee work commitment, and to reduce employee retirement related work stress. This assertion is made based on the responses of the majority $(67.1 \%, 54.4 \%$ and $59.9 \%)$ of the respondents to questionnaire items that addressed the research objective as reflected in Table 2 . The finding corroborates of the findings of Chizueze et al. (2011) that contributory pension scheme significantly affects workers' commitment to work, retention, and attitude towards retirement in the Nigerian Civil Service. The finding validates the finding of Eze and Anikeze (2018) that Contributory Pension Scheme has had positive effect on workers' job satisfaction.

The research hypothesis, which states that there is a significant relationship between the new Contributory Pension Scheme and improved employee work attitude in the federal civil service, Imo State, was tested using chi-square statistic. The chi-square 
test showed a significant relationship $(p<0.05)$ between the new Contributory Pension Scheme and improved work attitude 0.000 for $\mathrm{X}^{2}=70.191, \mathrm{df}=8, p=0.000$. Hence, the research hypothesis was accepted. The result lends support to the finding of Eze and Anikeze (2018) that the contributory pension scheme has enhanced workers attitude to work. In explaining this result, it can be stated that the knowledge that retirement benefits would be paid as at when due helps to reduce the employees' retirement related work stress which is likely to lead to enhanced job satisfaction and work commitment. This line of reasoning is consistent with the expectancy theory which suggests that individuals (employees) will be motivated to put in effort and to achieve a level of performance, if they think that such behaviors will lead to desirable outcomes such as timely and adequate pensions.

\section{Conclusion}

The Contributory Pension Scheme was introduced by the Obasanjo-Led Administration to overcome the shortcomings of the Definite Benefit (Pay-As-You-Go) Pension Scheme which include huge pension cost, inadequate pension funds, payment of pensions to ineligible persons, and late payment of pensions. The administration recognized that the inadequacies of the Definite Benefit Pension Scheme have grave socioeconomic consequences for retirees, and likely dampens the spirit of active civil servants. Hence, the need to introduce a pension scheme, that could guarantee some level of postretirement security to motivate active civil servants. The Contributory Pension Scheme has no doubt elicited mixed feeling; some applaud the scheme, while some consider it to be ineffectual. This study therefore considered it germane to investigate the effect of the Contributory Pension Scheme on employee work attitude in the federal civil service in Imo State. The study concludes that the Contributory Pension Scheme has helped to reduce employee work-related stress and to improve employee job satisfaction and work commitment, conditions which contribute to pro-organizational behaviours such as organizational identification and work efficiency. The implication is that the Contributory Pension Scheme has had some positive effects on employee work attitude in the Nigerian Federal Civil Service at Imo State. For this reason, the author recommends that the Nigerian government should strengthen the administration and implementation of the contributory pension scheme to further improve the civil servants' work attitude and efficiency across the country.

\section{Acknowledgement}

Special thanks to Professor Nkemdili A. Nonyelu for his painstaking supervision of this research.

\section{Conflicts of interest}

The author declares that they no have conflicts of interest.

\section{References}

Abuja. National Pension Commission. Available from: <https://www.pencom.gov.ng/anoverview-of-contributory-pension-scheme/>. Accessed on: Feb. 20, 2021.

Adegoroye, G. Public service reform for sustainable development: The Nigerian Experience'. Keynote Address at the Commonwealth Advanced Seminar at Wellington New Zealand, 2006. 
Agba, A. M. O.; Ikoh, M. U.; Ushie, E. M.; Agba, M. S. Bureaucratic corruption in Nigeria: The need for institutional reforms. Journal of International Politics and Developmental Studies, v. 4, n. 1/2, p. 187-204, 2008.

Ahmad, M. K. Contributory pension scheme as instrument for liability controls for the states: Issues and prospects. Interaction with Nigerian Governors Forum, 2020.

Allen, S. G.; Clark, R. L. Pensions and firm performance. Cambridge: National Bureau of Economic Research, 1987. (Working Paper No. 2266). https://doi.org/10.3386/w2266

Ayegba, O.; James, I.; Odor, L. An evaluation of pension administration in Nigeria. British Journal of Arts and Social Sciences, v. 15, n. 11, 97-108, 2013.

Barrow, G. Pension Fund Administration in Nigeria. Abuja: Pen and Pages, 2008.

Campbell, J. P.; Dunnette, M. D.; Lawler, E. E.; Weick, K. E. Managerial behaviour, performance and effectiveness. New York: McGraw-Hill, 1970.

Chizueze, C. I.; Nwosu, U. W.; Agba, A. M. O. Contributory pension scheme, workers commitment, retention, and attitude towards Retirement in the Nigeria Civil Service. Global Journal of Management and Business Research, v. 2, n. 4, p. 51-59, 2011.

Cole, G. A. Management: Theory and practice. 5. ed. London: Continuum, 1996.

Daguada, A. T.; Adeyinka, O. P. An analysis of the impact of the 2004 pension policy on the welfare of the Nigerian civil servant: A case study of selected federal ministries. Global Journal of Human Resource Management, v. 1, n. 4, p. 20-55, 2013.

Dorsey, S.; Cornwell, C.; Macpherson, D. Pensions and productivity. Michigan: W. E. Upjohn Institute for Employment Research, 1998.

Edogbanya, A. An assessment of the impact of contributory pension scheme to Nigerian economic development. Global Journal of Management and Business Research, v. 13, n. 2, p. 47-59, 2013.

Egye, A. U.; Uthman, A. A. The impact of 2004 Pension Reform Act on Productivity in Nigeria: A study of Federal Polytechnic, Nasarawa 2004-2007. African Journal of Law, Political Research and Administration, v. 1, n. 1, p. 54-65, 2018.

Eze, F. O.; Anikeze, N. H. Effects of contributory pension scheme on workers' performance in Nigerian universities: A study of federal universities in South East Nigeria. Journal of Administration, v. 3, n. 2, p. 65-88, 2018.

Graen, G. Instrumentality theory of work motivation: Some experimental results and suggested modifications. Journal of Applied Psychology, v. 53, n. 2 pt. 2, p. 1-25, 1969. https://doi.org/10.1037/h0027100

Iheriohanma, E. Perceiving workers' interest in participatory management: Issues and challenges. International Journal of Social Sciences, v. 5, p. 113-129, 2006.

Kotun, A. I.; Adeoye, A. O.; Alaka, N. S. Effects of contributory pension scheme on employees' productivity: Evidence from Lagos state government. African Journal of Business Management, v. 10, n. 16, p. 384-396, 2016. https://doi.org/10.5897/ AJBM2016.8102

Kwaghaga, B. Civil service reforms in Nigeria and challenges of national development. Journal of Arts and Contemporary Society, v. 2, p. 104-113, 2010.

Lawal, T.; Oluwatoyin, A. The civil service and sustainable development in Nigeria. Journal of Sustainable Development in Africa, v. 13, n. 4, p. 385-393, 2011. 
Lawler, E. E. Pay and organizational effectiveness: A psychological view. New York: McGraw-Hill, 1971.

National Pension Commission. Pension Reform Act 2004 (No. 2). 2014. Available from: $<$ https://www.pencom.gov.ng/download/faq/Nigeria_PensionReformAct2004>. Accessed on: Feb. 20, 2021.

National Pension Commission. Pension Reform Act 2014. 2018. Available from: <https://www.pencom.gov.ng/wp-content/uploads/2018/01/PRA_2014.pdf>. Accessed on: Feb. 20, 2021.

Obasanjo, O. The imperative of civil service reform. In: Adegoroye, G. (Ed.). Nigeria Public Service Reform: The visions and challenges. Abuja: Bureau of Public Service Reforms, 2004.

Okonjo-Iweala, N.; Osafo-Kwaako, P. Nigeria's economic reforms: Progress and challenges. Washington, DC: The Brookings Institution, 2007. (Brookings Global Economy and Development Working Paper, No. 6). https://doi.org/10.2139/ssrn.1080251

Robbins, S. P.; Judge, T. A. Essentials of organizational behaviour. 9. ed. New Jersey: Pearson Prentice Hall, 2008.

Sule, K. O.; Ezugwu, C. I. Evaluation of the application of contributory pension scheme on employee retirement benefit of quoted firms in Nigeria. African Journal of Accounting, Economics, Finance and Banking Research, v. 4, n. 4, p. 48-58, 2009.

Unanka, G. O. Methodology of social science research. 3. ed. Lagos: Sam Iroanusi, 2008.

Vanguard Newspaper. Maina Pension Scam. February 14, 2013. Available from: <http://www.vanguardngr.com /2013/pension-scam-more-schocking-revelation-comingmaina>. Accessed on: Feb. 18, 2021.

Vroom, V. H. Work and motivation. New York: John Wiley, 1964.

License information: This is an open-access article distributed under the terms of the Creative Commons Attribution License, which permits unrestricted use, distribution, and reproduction in any medium, provided the original work is properly cited. 